\title{
Characterization of Protamine Uptake by Opossum Kidney Epithelial Cells
}

\author{
Junya Nagai, Takuji Komeda, Yuki Katagiri, Ryoko Yumoto, and Mikihisa Takano* \\ Department of Pharmaceutics and Therapeutics, Graduate School of Biomedical \& Health Sciences, Hiroshima \\ University; 1-2-3 Kasumi, Minami-ku, Hiroshima 734-8553, Japan. \\ Received July 13, 2013; accepted September 24, 2013
}

\begin{abstract}
Protamine, a mixture of polypeptides that is rich in arginine, has been used clinically as an antidote to heparin overdoses and a complexing agent in a long-acting insulin preparation. When protamine is administered intravenously, its abundant accumulation in the kidneys has been reported. However, the renal uptake mechanism for protamine is not clear. In this study, we examined the transport mechanism for protamine in opossum kidney $(\mathrm{OK})$ cells, a suitable in vitro model for renal proximal tubular epithelial cells. Flow cytometric analysis revealed that the association of fluorescein isothiocyanate (FITC)-labeled protamine from salmon (FITC-protamine) by OK cells was inhibited by unlabeled protamine in a concentration-dependent manner. The association of FITC-protamine was temperature- and energy-dependent. Confocal microscopy analysis showed that the fluorescence was localized in the cytoplasm and nucleus of OK cells. In addition, FITC-protamine association was inhibited by cationic drugs such as polycationic gentamicin and polymixin $B$, but it was increased by a basic amino acid, arginine. Inhibitors for clathrin- and caveolin-dependent endocytosis showed inhibitory effects on FITC-protamine association. Pretreatment with heparinase III partially but significantly decreased the association of FITC-protamine. These results suggest that protamine may be taken up by $\mathrm{OK}$ cells via receptor-mediated endocytosis, which may result in its localization in the cytoplasm and nucleus of the cells.
\end{abstract}

Key words protamine; endocytosis; renal proximal tubular cell; opossum kidney cell; polycationic drug

Protamines are small nuclear proteins that are very basic due to their high arginine contents. They are usually isolated from the sperm of salmon and certain other fish species. Protamine binds to heparin, which is strongly acidic, through an electrostatic interaction, and forms a stable salt that abolishes the anticoagulant activity of heparin. Therefore, protamine sulfate is regularly used following a cardiopulmonary bypass and cardiac catheterization to reverse the anticoagulant activity of heparin. ${ }^{1)}$ In addition, it is prevalently used as a complexing agent in the formulation of long-acting insulin products. ${ }^{2}$ Furthermore, protamine is known to complex and condense DNA from an extended conformation to highly compact structures, and to possess several amino acid sequences resembling that of a nuclear localization signal. Therefore, protamine has been developed as a carrier for gene delivery. ${ }^{3-5)}$ Thus, protamine has been employed for various purposes in clinical and preclinical stages.

In spite of the clinical application of protamine sulfate for decades, there have only been a few reports on the pharmacokinetics and tissue distribution of injected protamine. ${ }^{6-8)}$ DeLucia et $a l{ }^{6)}$ showed that the radioactivity per gram tissue was highest in the kidneys at $3 \mathrm{~min}$ after an intravenous administration of ${ }^{125} \mathrm{I}$-labeled protamine to rats, the blood halflife being $24 \mathrm{~min}$. However, it is not clear whether the radioactivity in tissues after an injection of radiolabeled protamine results from the distribution of an intact form of protamine or its degraded products in tissues.

We recently reported that protamine, as well as other cationic proteins and peptides, inhibits the uptake of a nephrotoxic drug, gentamicin, which is highly accumulated in the kidneys, by cultured opossum kidney (OK) epithelial cells. ${ }^{9}{ }^{9}$ OK is a renal tubular epithelial cell line expressing megalin and

The authors declare no conflict of interest cubilin, ${ }^{10)}$ multiligand endocytic receptors that play important roles in renal endocytic uptake of low-molecular weight proteins, albumin, and cationic drugs such as gentamicin passing through the glomerulus. ${ }^{11,12}$ Therefore, we suggested that protamine might decrease the uptake of gentamicin by interacting with the endocytic receptor that is involved in gentamicin binding to the plasma membrane surface.9)

Protamine and its low-molecular weight fragments are reported to exhibit membrane-translocating activity comparable to those of other cell-penetrating peptides (CPPs) such as the human immunodeficiency virus (HIV) TAT peptide. ${ }^{5,13,14}$ Reynolds et $\mathrm{al}^{5)}$ reported strong nuclear localization of fluorescent-labeled protamine in HeLa cells and Caco- 2 cells, a human cervical cancer cell line and a human colon carcinoma cell line, respectively. Park et al. ${ }^{13)}$ showed that low-molecular weight fragments derived from protamine accumulated in the cytoplasm and nucleus of 293T human embryonic kidney transformed cells. However, the molecular mechanisms underlying the cellular uptake of protamine have not been fully elucidated.

The aim of this study was to characterize the uptake of protamine by OK cells, which are widely employed as an in vitro model of renal proximal tubular epithelia cells., ${ }^{9,10,15-17)}$ The present findings indicated that protamine is taken up in energy- and temperature-dependent manners, and that its internalization is mediated via receptor-mediated, and partially via clathrin- and caveolin-dependent, endocytosis.

\section{MATERIALS AND METHODS}

Materials Protamine sulfate from salmon, 2,4-dinitrophenol, gentamicin sulfate, polymixin B sulfate, and chlorpromazine hydrochloride were obtained from Nacalai Tesque (Kyoto, Japan). Fluorescein isothiocyanate, fluorescein isothiocya- 
nate (FITC)-labeled bovine serum albumin (FITC-albumin), phenylarsine oxide, nystatin, 5-( $N$-ethyl- $N$-isopropyl)amiloride (EIPA), cytochalasin D and heparinase III from Flavobacterium heparinum were purchased from Sigma-Aldrich (St. Louis, MO, U.S.A.). L-Arginine monohydrochloride, $\gamma$-globulin from human serum, methyl- $\beta$-cyclodextrin and Hoechst 33342 were purchased from Wako Pure Chemical Industries, Ltd. (Osaka, Japan). D-Mannitol was obtained from Kanto Chemical Co., Inc. (Tokyo, Japan). All other chemicals used in the experiments were commercial products of the highest purity available.

Preparation of FITC-Protamine Labeling of protamine with FITC was performed as follows. Briefly, $37 \mathrm{mg}$ FITC and $400 \mathrm{mg}$ protamine sulfate were dissolved in $0.1 \mathrm{M}$ borate buffer ( $\mathrm{pH}$ 9.0). After incubation for $4 \mathrm{~h}$ at room temperature, the $\mathrm{pH}$ of the mixture was adjusted to 7.5 with $0.8 \mathrm{M}$ boric acid. The solution was then dialyzed with a cellulose membrane for $90 \mathrm{~h}$ at $4^{\circ} \mathrm{C}$ and then concentrated by freeze-drying. To remove unbound FITC completely, the lyophilized products were subjected to gel filtration on a Sephadex G-15 column (2.1 by $40 \mathrm{~cm}$ ), using $0.1 \%$ trifluoroacetic acid (TFA) in distilled water as the mobile phase. The fractions that were collected by measuring fluorescence intensity (Ex. $500 \mathrm{~nm}$, Em. $520 \mathrm{~nm}$ ) were dialyzed to remove TFA with a cellulose membrane for $24 \mathrm{~h}$ at $4^{\circ} \mathrm{C}$, and then concentrated by freeze-drying. The lyophilized proteins were used as FITC-protamine and were stored in a $-30^{\circ} \mathrm{C}$ freezer until use. The mass spectra of unlabeled protamine and FITC-protamine are shown in Supplemental Fig. 1.

Cell Culture OK cells were cultured in medium 199 (Gibco BRL., Life Technologies, Grand Island, NY, U.S.A.) containing $10 \%$ fetal bovine serum without antibiotics, under an atmosphere of $5 \% \mathrm{CO}_{2}-95 \%$ air at $37^{\circ} \mathrm{C}$, and subcultured every $7 \mathrm{~d}$ using $0.05 \%$ trypsin and $0.02 \%$ ethylenediaminetetraacetic acid (EDTA). The medium was replaced with fresh medium every $2 \mathrm{~d}$, and the cells were used for the experiments at $5-7 \mathrm{~d}$ after seeding.

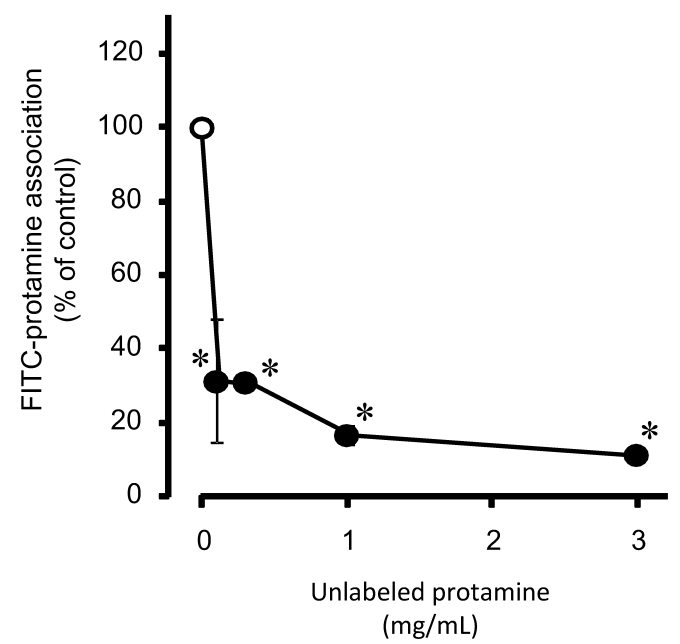

Fig. 1. Effect of Unlabeled Protamine on the Association of Fluorescein Isothiocyanate-Labeled Protamine (FITC-Protamine) by OK Cells

OK cells were incubated with FITC-protamine $(30 \mu \mathrm{g} / \mathrm{mL})$ for $60 \mathrm{~min}$ at $37^{\circ} \mathrm{C}$ in the absence (control, open circle) or presence (closed circles) of unlabeled protamine at various concentrations $(0.1,0.3,1$ and $3 \mathrm{mg} / \mathrm{mL})$. Then, the cells were washed, harvested with trypsin/EDTA and analyzed by flow cytometry. The effect of unlabeled protamine on FITC-protamine association is shown relative to the fluorescence in the absence of unlabeled protamine (control). Each symbol represents the mean \pm S.E. of three determinations. $* p<0.05$, significantly different from the value in the absence of unlabeled protamine (control).
Flow Cytometry Uptake studies were performed on the confluent cells attached to 12 -well plates. Experiments were performed in Dulbecco's phosphate-buffered saline (PBS buffer containing, in $\mathrm{mm}, 137 \mathrm{NaCl}, 3 \mathrm{KCl}, 8 \mathrm{Na}_{2} \mathrm{HPO}_{4}, 1.5$ $\mathrm{KH}_{2} \mathrm{PO}_{4}, 1 \mathrm{CaCl}_{2}$ and $0.5 \mathrm{MgCl}_{2}$ ). PBS buffer containing $5 \mathrm{~mm}$ D-glucose [PBS $(\mathrm{G})$ buffer] was used as an incubation buffer. After removal of the culture medium, each well was washed and preincubated with $\operatorname{PBS}(G)$ buffer. Then, $\operatorname{PBS}(G)$ buffer containing FITC-protamine or FITC-albumin was added to each well, and the cells were incubated at $37^{\circ} \mathrm{C}$ or $4^{\circ} \mathrm{C}$ for a specified period. At the end of the incubation, the cells were rinsed rapidly three times with $1 \mathrm{~mL}$ of ice-cold PBS buffer. Then, the cells were incubated with $500 \mu \mathrm{L}$ of phosphate buffer containing $0.05 \%$ trypsin and $0.02 \%$ EDTA for $20 \mathrm{~min}$ at $37^{\circ} \mathrm{C}$ to detach the cells and to remove surface-bound compounds. The cells were centrifuged at $4{ }^{\circ} \mathrm{C}$ for $5 \mathrm{~min}$ at $10000 \mathrm{rpm}$ and the supernatant was discarded. The cells were suspended in $500 \mu \mathrm{L}$ of a buffer [10 mM $N$-(2-hydroxyethyl)piperazine- $N$ '-2-ethanesulfonic acid (HEPES)/ $\mathrm{NaOH}(\mathrm{pH} 7.5)$, $150 \mathrm{~mm} \mathrm{NaCl}, 5 \mathrm{~mm} \mathrm{KCl}, 1 \mathrm{~mm} \mathrm{MgCl}_{2}, 1.8 \mathrm{~mm} \mathrm{CaCl}_{2}$, and analyzed immediately with a flow cytometer (EPICS XL, Beckman Coulter, Tokyo, Japan) using $\mathrm{EXPO}^{\mathrm{TM}} 32$ MultiCOMP software (Beckman Coulter). In each assay, the fluorescence of 10000 cells was analyzed.

Confocal Laser Scanning Microscopy OK cells were cultured in $35-\mathrm{mm}$ glass-bottom dishes for $5 \mathrm{~d}$. The cells were incubated with FITC-protamine $(500 \mu \mathrm{g} / \mathrm{mL})$ for $60 \mathrm{~min}$ at $37^{\circ} \mathrm{C}$ or $4^{\circ} \mathrm{C}$. At $30 \mathrm{~min}$ before the end of the incubation, Hoechst $33342(10 \mu \mathrm{M})$ was added to the incubation buffer containing FITC-protamine. After being washed with icecold PBS buffer three times, the live cells were viewed using a confocal laser scanning fluorescence microscope (LSM510 invert., Carl Zeiss, Göttingen, Germany).

Cell Treatment To examine the effects of various compounds on the uptake of FITC-protamine, OK cells were preincubated with $\mathrm{PBS}(\mathrm{G})$ buffer in the absence or presence of each compound at $37^{\circ} \mathrm{C}$. Pretreatment with 2,4-dinitrophenol (1 $\mathrm{mm}$ ) was performed for $15 \mathrm{~min}$, followed by coincubation with FITC-protamine for $60 \mathrm{~min}$. Pretreatment with phenylarsine oxide $(10 \mu \mathrm{M})$ was performed for $15 \mathrm{~min}$, but it was not present during the incubation with FITC-protamine. Pretreatment with chlorpromazine $(50$ or $100 \mu \mathrm{M})$, nystatin $(10,25$ or $50 \mu \mathrm{M})$, methyl- $\beta$-cyclodextrin (5 mM), and EIPA (50 or $100 \mu \mathrm{M})$ was performed for $30 \mathrm{~min}$, followed by coincubation with FITC-protamine for $60 \mathrm{~min}$. Pretreatment with cytochalasins B and D $(20 \mu \mathrm{M})$ was performed for $120 \mathrm{~min}$, followed by coincubation with FITC-protamine for $60 \mathrm{~min}$. Pretreatment with heparinase III $(10,30$ or $100 \mathrm{mU})$ was performed for $60 \mathrm{~min}$, but it was not coincubated with FITC-protamine. After the preincubation, the cells were washed three times, and the uptake assay was performed as described above. For hypertonic conditions, $400 \mathrm{~mm}$ mannitol was added to the incubation buffer containing FITC-protamine. The control cells were treated with the same concentration of dimethyl sulfoxide (DMSO) $(0.5 \%)$ in each experiment.

Preparation of Brush-Border Membranes from Rat Kidney Experiments involving animals were performed in accordance with the Guide for Animal Experimentation, Hiroshima University, and the Committee of Research Facilities for Laboratory Animal Sciences, Graduate School of Biomedical \& Health Sciences, Hiroshima University. Renal 
brush-border membranes were isolated from the renal cortices of male Wistar albino rats $(190-220 \mathrm{~g})$. The isolation procedure for renal brush-border membranes was based on the $\mathrm{Mg}$ / ethylene glycol bis(2-aminoethyl ether)- $N, N, N^{\prime}, N^{\prime}$-tetraacetic acid (EGTA) precipitation method described previously. ${ }^{18)}$ The isolated membranes were suspended in a buffer comprising $100 \mathrm{~mm}$ mannitol and $10 \mathrm{~mm}$ HEPES/Tris ( $\mathrm{pH} 7.5)$, and stored in liquid nitrogen until use.

Western Blot Analysis and Ligand Blotting The crude membrane fraction derived from $\mathrm{OK}$ cells was prepared on the sixth day after seeding as described below. Briefly, after removal of the culture medium, each dish was washed with ice-cold PBS buffer and the cells were collected with a rubber policeman. The cell suspension was homogenized for $2 \mathrm{~min}$ with an IKA T25 Basic disperser (IKA LABORTECHNIK, Germany) in an ice-cold preparation buffer $(150 \mathrm{~mm} \mathrm{NaCl}$, $5 \mathrm{~mm}$, EDTA, $1 \mathrm{~mm}$ phenylmethylsulfonyl fluoride (PMSF), $10 \mathrm{~mm}$ Tris, $\mathrm{pH}$ 7.4), and was subsequently homogenized with a glass/Teflon Potter homogenizer, 10 strokes, at $1000 \mathrm{rpm}$. The homogenate was centrifuged at $3000 \times \boldsymbol{g}$ for $15 \mathrm{~min}$ at $4^{\circ} \mathrm{C}$. The supernatant was centrifuged at $15000 \times \mathbf{g}$ for $15 \mathrm{~min}$ at $4^{\circ} \mathrm{C}$, and the resulting supernatant was centrifuged at $100000 \times \boldsymbol{g}$ for $1 \mathrm{~h}$ at $4^{\circ} \mathrm{C}$. The pellet was resuspended in an ice-cold preparation buffer comprising $1 \%$ Triton X-100, $0.1 \%$ sodium dodecyl sulfate (SDS) and $1 \%$ sodium deoxycholate, and then left for $30 \mathrm{~min}$ on ice with vortex mixing about every $10 \mathrm{~min}$. Then, the lysate was centrifuged at $8000 \times \mathbf{g}$ for $3 \mathrm{~min}$ at $4^{\circ} \mathrm{C}$. The supernatant, which contained crude membrane fractions of OK cells, was mixed with a loading buffer. The brush-border membranes of rat renal cortices were used for comparison. The samples $(100 \mu \mathrm{g} /$ lane for OK cells, $22.5 \mu \mathrm{g} /$ lane for rat renal brush-border membrane) were subjected to SDS-polyacrylamide gel electrophoresis on 4-15\% precast linear gradient polyacrylamide gradient gels (Bio-Rad Laboratories, Hercules, CA, U.S.A.), and the proteins were transferred for $75 \mathrm{~min}$ to polyvinylidene difluoride (PVDF) membranes at $4^{\circ} \mathrm{C}$. For Western blotting, each membrane was blocked in $5 \%$ non-fat dry milk in Tris-buffered saline (TBS, $150 \mathrm{~mm} \mathrm{NaCl}$, $20.5 \mathrm{~mm}$ Tris, pH 7.4) containing $0.05 \%$ Tween 20 (TBS-T) overnight at $4^{\circ} \mathrm{C}$. The membrane was washed twice for $5 \mathrm{~min}$ in TBS-T and once for $5 \mathrm{~min}$ in TBS. Then, the membrane was incubated with anti-cubilin goat antibodies (T-16, Santa Cruz Biotechnology, Inc., Santa Cruz, CA, U.S.A.) (1:100 dilution). The membrane was washed three times in TBS-T, and then incubated with horseradish peroxidase-conjugated anti-goat donkey immunoglobulin G (IgG) antibodies (Santa Cruz Biotechnology, Inc.) (1:500 dilution), washed three times in TBS-T, and visualized with enhanced chemiluminescence (Pierce Western Blotting Substrate Plus, Thermo Scientific, Rockford, IL, U.S.A.). The blot was visualized with a luminescent image analyzer (LAS 4000plus, GE Healthcare Japan Corporation, Tokyo, Japan). For ligand blotting with FITC-protamine, the PVDF membrane was blocked in $40 \mathrm{mg}$ / $\mathrm{mL}$ bovine serum $\gamma$-globulin in TBS-T overnight at $4^{\circ} \mathrm{C}$. The membrane was then washed twice for $5 \mathrm{~min}$ in TBS-T and once for $5 \mathrm{~min}$ in TBS. The membrane was incubated with PBS buffer containing $10 \mu \mathrm{g} / \mathrm{mL}$ FITC-protamine at $37^{\circ} \mathrm{C}$ for $1 \mathrm{~h}$. The membrane was then washed twice for $5 \mathrm{~min}$ in TBS-T and once for $5 \mathrm{~min}$ in TBS. The blot was visualized using a Typhoon FLA 7000 imaging system (GE Healthcare Japan Corporation). Protein was determined by the method of
Bradford $^{19)}$ with bovine serum albumin as the standard.

Data Analysis The half-maximal inhibitory concentration $\left(\mathrm{IC}_{50}\right)$ value was determined by means of the Hill equation using the KaleidaGraph ${ }^{\mathrm{TM}}$ program (Version 3.08, Synergy Software, PA, U.S.A.) for curve-fitting as described previously. ${ }^{20)}$ Statistically significant differences were evaluated by one-way analysis of variance with Tukey-Kramer's test for post hoc analysis. A $p$ value of less than 0.05 was considered statistically significant.

\section{RESULTS}

Effect of Unlabeled Protamine on FITC-Protamine Association by OK Cells First, we examined whether or not FITC-protamine is taken up by OK cells via a specific uptake system. Unlabeled protamine inhibited the association of FITC-protamine $(30 \mu \mathrm{g} / \mathrm{mL})$ at $37^{\circ} \mathrm{C}$ for $60 \mathrm{~min}$ in a concentration-dependent manner, the $\mathrm{IC}_{50}$ value being $16.4 \mu \mathrm{g} / \mathrm{mL}$ (Fig. 1). This observation indicates that FITC-protamine was internalized into the cells via a specific transport pathway. Furthermore, by employing the data shown in Fig. 1, the Michaleis constant $K_{\mathrm{m}}$ value of the association of protamine was estimated to be $202 \mu \mathrm{g} / \mathrm{mL}$ (see Supplemental Fig. 2).

Time-Course of FITC-Protamine Association by OK Cells The time-course of FITC-protamine association was examined, as shown in Fig. 2A. The association of FITC-protamine increased with time until $30 \mathrm{~min}$, and thereafter it lev-

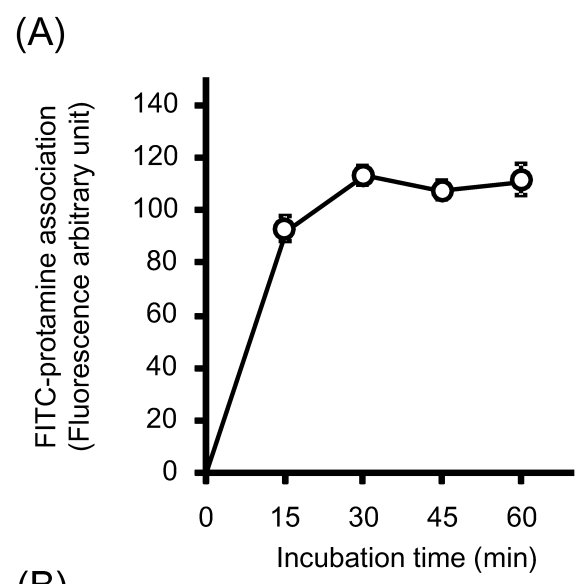

(B)

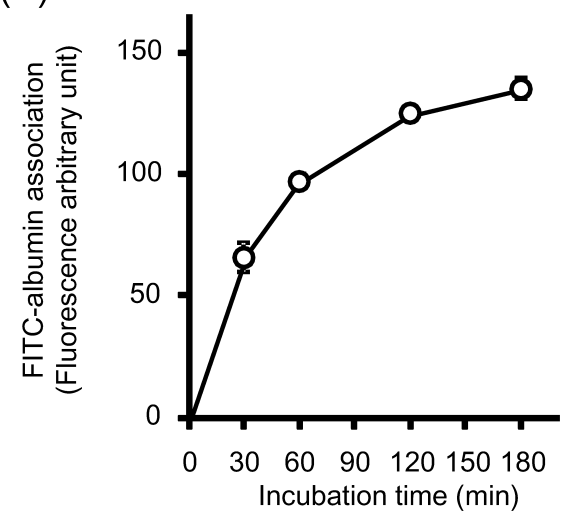

Fig. 2. Time Courses of the Association of FITC-Protamine and FITCAlbumin by OK Cells

OK cells were incubated with FITC-protamine $(30 \mu \mathrm{g} / \mathrm{mL})$ at $37^{\circ} \mathrm{C}$ for $15,30,45$ and $60 \mathrm{~min}(\mathrm{~A})$, or FITC-albumin $(30 \mu \mathrm{g} / \mathrm{mL})$ at $37^{\circ} \mathrm{C}$ for $30,60,120$ and $180 \mathrm{~min}$ (B). Then, the cells were washed, harvested with trypsin/EDTA and analyzed by flow cytometry. Each symbol represents the mean \pm S.E. of three determinations. 
eled off. On the other hand, the association of FITC-albumin, a ligand that is taken up via receptor-mediated endocytosis by renal proximal tubular epithelial cells, reached the maximum level at around $180 \mathrm{~min}$ (Fig. 2B). Thus, the maximal association of FITC-protamine was observed within a shorter incubation period as compared to that of FITC-albumin.

Temperature- and Metabolic Energy-Dependent Association of FITC-Protamine by OK Cells In order to examine the effect of incubation temperature on FITC-protamine uptake, cells were incubated with buffer including $30 \mu \mathrm{g} / \mathrm{mL}$ FITC-protamine at $37^{\circ} \mathrm{C}$ or $4^{\circ} \mathrm{C}$. As shown in Fig. 3, the association of FITC-protamine at $37^{\circ} \mathrm{C}$ was significantly greater than that at $4^{\circ} \mathrm{C}$. Furthermore, the effect of DNP, an uncoupler

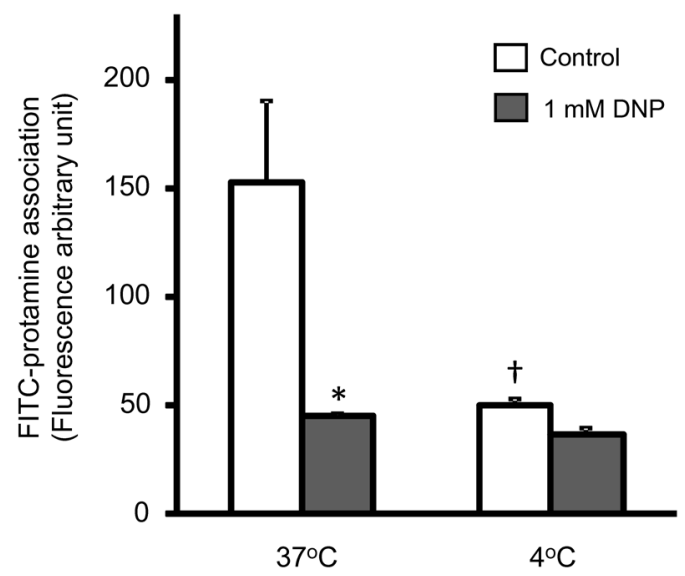

Fig. 3. Effects of 2,4-Dinitrophenol (DNP) and Temperature on the Association of FITC-Protamine by OK Cells

OK cells were incubated with FITC-protamine $(30 \mu \mathrm{g} / \mathrm{mL})$ at $37^{\circ} \mathrm{C}$ or $4{ }^{\circ} \mathrm{C}$ for $60 \mathrm{~min}$ in the absence (open columns) or presence (gray columns) of $1 \mathrm{~mm}$ DNP. Then, the cells were washed, harvested with trypsin/EDTA and analyzed by flow cytometry. Each column represents the mean \pm S.E. of three determinations ${ }^{*} p<0.05$, significantly different from the value in the absence of DNP at each incubation temperature. ${ }^{\dagger} p<0.05$, significantly different from the value under each conditions at $37^{\circ} \mathrm{C}$. of oxidative phosphorylation, on FITC-protamine uptake was examined. Treatment with $1 \mathrm{~mm}$ 2,4-dinitrophenol (DNP) significantly inhibited the association of FITC-protamine at $37^{\circ} \mathrm{C}$, but not at $4^{\circ} \mathrm{C}$ (Fig. 3). These results indicate that the uptake of FITC-protamine is dependent on temperature and metabolic energy.

Intracellular Localization of FITC-Protamine Taken Up by OK Cells Intracellular localization of FITC-protamine was examined by confocal laser scanning microscopy (Fig. 4). After $\mathrm{OK}$ cells had been incubated with FITC-protamine at $37^{\circ} \mathrm{C}$ or $4^{\circ} \mathrm{C}$ for $30 \mathrm{~min}$, confocal microscopy analysis was performed on live OK cells in order to avoid fixation artifacts that were suggested in uptake studies on CPPs. ${ }^{21,22)}$ When FITC-protamine was incubated with $\mathrm{OK}$ cells at $37^{\circ} \mathrm{C}$, punctate and diffuse fluorescence was observed in the cytoplasm of the cells. In addition, staining of the nuclear membrane and nuclei was clearly observed. The fluorescence in the nuclei was not spread evenly but concentrated in certain spots on them. In contrast, little intracellular accumulation of fluorescence was observed when the $\mathrm{OK}$ cells were incubated at $4^{\circ} \mathrm{C}$ for $30 \mathrm{~min}$. However, interestingly, clear fluorescence was observed on the plasma membranes of the cells that had been incubated at $4^{\circ} \mathrm{C}$, but not at $37^{\circ} \mathrm{C}$.

Effects of Endocytosis Inhibitors on FITC-Protamine Association by OK Cells We characterized the molecular mechanisms underlying the internalization of FITC-protamine by $\mathrm{OK}$ cells. First, the effects of inhibitors of clathrindependent endocytosis on FITC-protamine were examined (Table 1). The inhibitors for clathrin-dependent endocytosis employed in this study were phenylarsine oxide, an inhibitor of clathrin-coat formation, and chlorpromazine, a cationic amphiphilic drug that induces the redistribution of a clathrincoated pit component AP-2 to endosomes. The two clathrindependent endocytosis inhibitors significantly decreased the association of FITC-protamine. Furthermore, we examined the effect of hypertonicity, which inhibits clathrin-coated pit
(A)

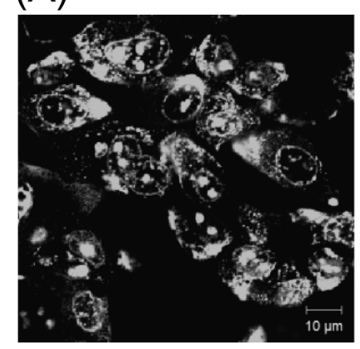

(D)

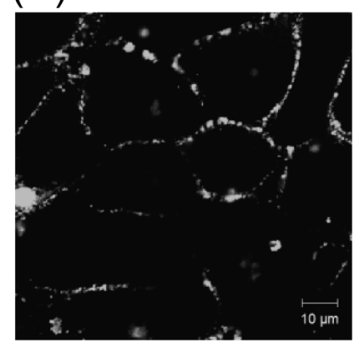

(B)

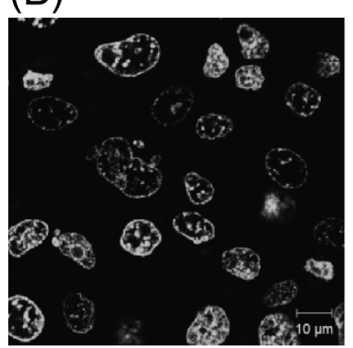

(E)

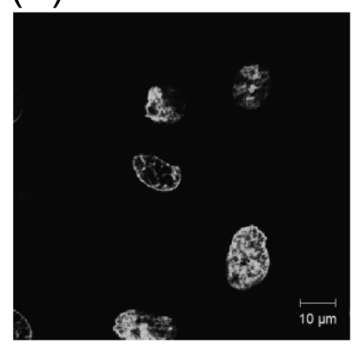

(C)

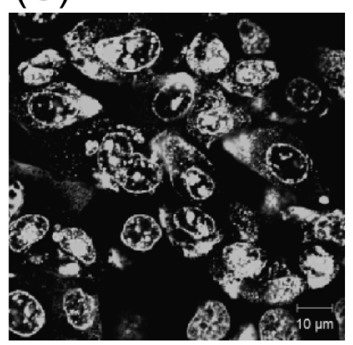

(F)

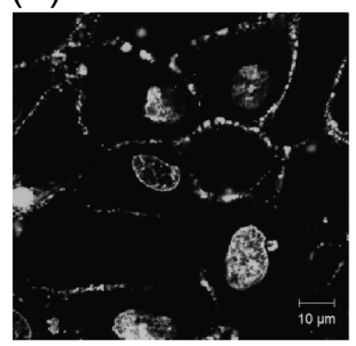

Fig. 4. Confocal Laser Scanning Micrographs of OK Cells Incubated with FITC-Protamine

OK cells were incubated with FITC-protamine $(500 \mu \mathrm{g} / \mathrm{mL})$ at $37^{\circ} \mathrm{C}\left(\mathrm{A}, \mathrm{B}\right.$ and C) or $4^{\circ} \mathrm{C}(\mathrm{D}, \mathrm{E}$ and F) for 60 min, including coincubation with $10 \mu \mathrm{M}$ Hoechst 33342 for 30 min. After being washed, the live cells were observed by confocal laser scanning microscopy. (A, D) FITC-protamine (green), (B, E) Hoechst33342 (blue), (C, F) merge. (Color images were converted into gray scale.) 
formation, on FITC-protamine association (Table 1). A high concentration of mannitol $(400 \mathrm{~mm})$ significantly decreased the association of FITC-protamine. Thus, these observations indicate that FITC-protamine association by $\mathrm{OK}$ cells is, at least in part, mediated by clathrin-dependent endocytosis. Next, we examined the effects of inhibitors of caveolin-de-

Table 1. Effects of Hypertonic Conditions, Various Endocytosis Inhibitors and Heparinase III on FITC-Protamine Association by OK Cells

\begin{tabular}{lc}
\hline \hline & $\begin{array}{c}\text { FITC-protamine association } \\
(\% \text { of control) }\end{array}$ \\
\hline $10 \mu \mathrm{m}$ Phenylarsine oxide & $54.5 \pm 2.6^{*}$ \\
$50 \mu \mathrm{M}$ Chlorpromazine & $63.8 \pm 2.7^{*}$ \\
$100 \mu \mathrm{M}$ Chlorpromazine & $14.9 \pm 0.5^{*}$ \\
$400 \mathrm{~mm}$ Mannitol & $57.1 \pm 4.6^{*}$ \\
$10 \mu \mathrm{m}$ Nystatin & $121.6 \pm 7.0$ \\
$25 \mu \mathrm{M}$ Nystatin & $130.8 \pm 5.1$ \\
$50 \mu \mathrm{M}$ Nystatin & $18.1 \pm 0.2^{*}$ \\
$5 \mathrm{~mm}$ Methyl- $\beta$-cyclodextrin & $42.4 \pm 2.6^{*}$ \\
$50 \mu \mathrm{M}$ EIPA & $73.2 \pm 2.1^{*}$ \\
$100 \mu \mathrm{M}$ EIPA & $53.6 \pm 4.3^{*}$ \\
$20 \mu \mathrm{M}$ Cytochalasin B & $111.1 \pm 3.6$ \\
$20 \mu \mathrm{M}$ Cytochalasin D & $113.8 \pm 4.5$ \\
$10 \mathrm{mU} / \mathrm{mL}$ Heparinase III & $105.5 \pm 2.7$ \\
$30 \mathrm{mU} / \mathrm{mL}$ Heparinase III & $86.5 \pm 2.7^{*}$ \\
$100 \mathrm{mU} / \mathrm{mL}$ Heparinase III & $71.8 \pm 4.5^{*}$ \\
\hline
\end{tabular}

OK cells were treated with various compounds as described under Materials and Methods. The association of FITC-protamine $(30 \mu \mathrm{g} / \mathrm{mL})$ after $60 \mathrm{~min}$ at $37^{\circ} \mathrm{C}$ was analyzed by flow cytometry. Values represent the means \pm S.E. of three determinations. $* p<0.05$, significantly different from the value without compound tested (control) EIPA, 5-( $N$-ethyl- $N$-isopropyl)amiloride.

(A)

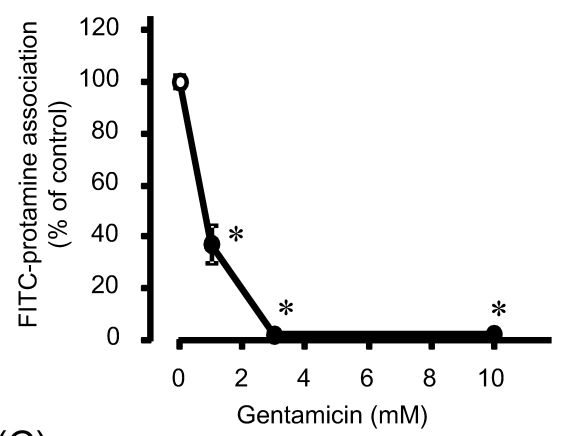

(C)

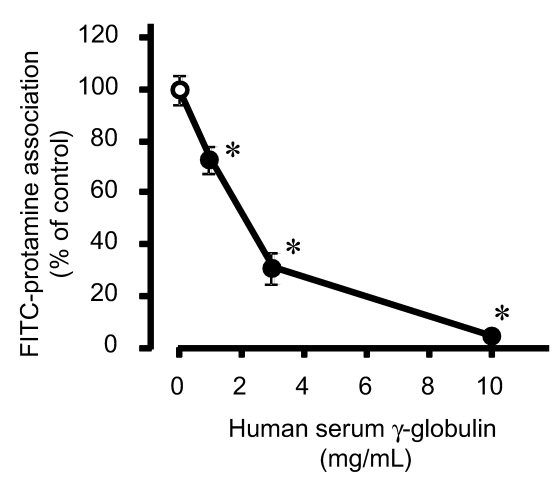

pendent endocytosis on FITC-protamine association (Table 1). Nystatin is a cholesterol-binding drug that inhibits caveolinmediated endocytosis. Methyl- $\beta$-cyclodextrin is a cholesterolsequestering drug that disrupts the caveolae integrity. The association of FITC-protamine was significantly inhibited by these caveolin-dependent endocytosis inhibitors. Thus, it is likely that caveolin-dependent endocytosis is also involved in FITC-protamine association by OK cells. In addition, the effects of macopinocytosis inhibitors on FITC-protamine association were examined (Table 1). EIPA, an analogue of an ion-exchange inhibitor, amiloride, decreased the association of FITC-albumin in a concentration-dependent manner, but other macropinocytosis inhibitors, cytochalasins B and D, did not inhibit FITC-protamine association. Thus, EIPA might decrease FITC-protamine association by indirectly or directly affecting a multitude of endocytic processes. ${ }^{23)}$

Effects of Cationic Compounds and Serum $\gamma$-Globulin on FITC-Protamine Association by OK Cells Since we reported that protamine inhibited gentamicin uptake by $\mathrm{OK}$ cells, ${ }^{9)}$ the effect of gentamicin on FITC-protamine association was examined. As shown in Fig. 5A, gentamicin inhibited the association of FITC-protamine in a concentration-dependent manner. In addition, polymixin $\mathrm{B}$, a cationic peptide antibiotic that binds to megalin, ${ }^{24,25)}$ greatly decreased the association of FITC-protamine (Fig. 5B). Furthermore, human serum $\gamma$-globulin, which decreases FITC-IgG uptake by OK cells, ${ }^{20)}$ also inhibited the association of FITC-protamine in a concentration-dependent manner (Fig. 5C). In contrast, arginine, a basic amino acid, did not inhibit, but rather enhanced the association of FITC-protamine (Fig. 5D).

(B)

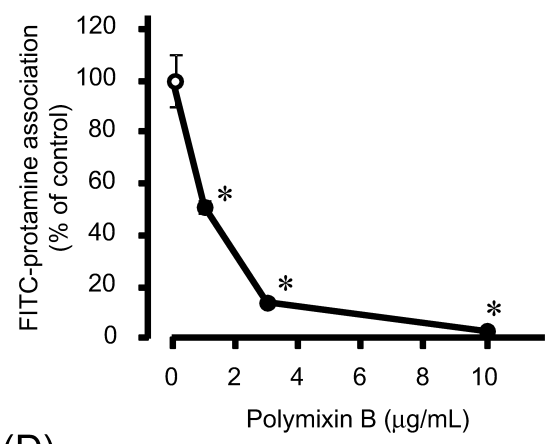

(D)

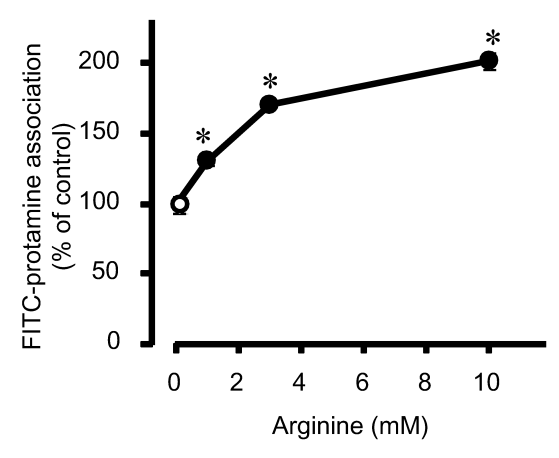

Fig. 5. Effects of Cationic Compounds and Serum $\gamma$-Globulin on the Association of FITC-Protamine by OK Cells

OK cells were incubated with FITC-protamine $\left(30 \mu \mathrm{g} / \mathrm{mL}\right.$ ) for $60 \mathrm{~min}$ at $37^{\circ} \mathrm{C}$ in the absence (control, open circle) or presence (closed circles) of various concentrations of gentamicin (A), polymixin B (B), human serum $\gamma$-globulin (C), or L-arginine (D). Then, the cells were washed, harvested with trypsin/EDTA and analyzed by flow cytometry. The effect of each compound on FITC-protamine association is shown relative to the fluorescence in the absence of its compound (control). Each symbol represents the mean \pm S.E. of three determinations. ${ }^{*} p<0.05$, significantly different from the value in the absence of compound tested (control). 
(A)

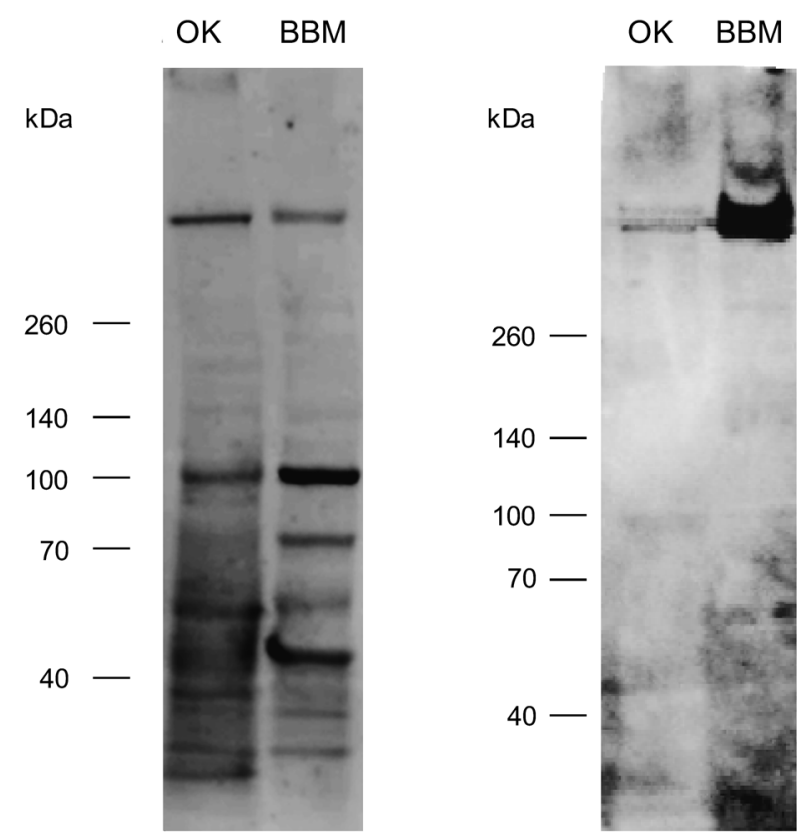

Fig. 6. Ligand Blotting with FITC-Protamine and Western Blotting with Anti-cubilin Antibodies for Crude Membranes from OK Cells and Brush-Border Membranes from Rat Renal Cortices

The crude membranes from OK cells and brush-border membranes from rat renal cortices were prepared as described under Materials and Methods. The membrane samples were separated by $4-15 \%$ gradient SDS-PAGE, and then transferred polyvinylidene difluoride (PVDF) membranes. Each PVDF membrane was incubated with FITC-protamine $(10 \mu \mathrm{g} / \mathrm{mL})(\mathrm{A})$ or anti-cubilin antibodies $(1: 100$ dilution) (B). The bands on ligand blotting (A) and Western blotting (B) were visualized with a fluorescence imaging system and enhanced chemiluminescence, respectively.

Effect of Heparinase Treatment on FITC-Protamine Association by OK Cells Heparan sulfate proteoglycans (HSPGs) are suggested to be involved in the internalization of CPPs. ${ }^{26,27)}$ Therefore, we investigated the effect of heparinase III, a heparin-degrading lyase that recognizes the ubiquitous cell-surface HSPGs, on FITC-protamine association. Pretreatment with heparinase III for $60 \mathrm{~min}$ decreased the association of FITC-protamine in a concentration-dependent manner (Table 1).

Ligand Blotting for Crude Membrane Fraction from OK Cells with FITC-Protamine To investigate the presence of membrane proteins that exhibit binding affinity for FITC-protamine, ligand blot analysis was performed using crude membrane fractions derived from OK cells and brushborder membranes from rat renal cortices. As shown in Fig. $6 \mathrm{~A}$, there were two major bands corresponding to apparent molecular sizes of 410 and $100 \mathrm{kDa}$, which were detected for membrane fractions from both $\mathrm{OK}$ cells and rat renal cortices. Figure 6B shows Western blot analysis of the two membrane fractions with anti-cubilin antibodies. Cubilin was detected in both membrane fractions, the bands corresponding to almost the same size as that of the higher molecular size observed on ligand blotting (Fig. 6B).

\section{DISCUSSION}

Here, a quantitative cellular uptake study was performed by flow cytometry. For the flow cytometric analysis, OK cells were detached from culture plates by trypsinization after incubation with FITC-protamine. Therefore, the fluorescence intensity that was detected with the flow cytometer is considered to represent the amount of FITC-protamine that was internalized into the cells since the FITC-protamine adsorbed to the plasma membrane would be removed during trypsinization, as suggested for the protocol of flow cytometry analysis of translocation mechanisms for CPPs. ${ }^{21,22,27)}$ Furthermore, live cells without fixation were employed for the confocal microscopic analysis, which was performed to investigate the intracellular localization of FITC-protamine, because the cell fixation procedure is reported to lead to artificial redistribution of CPPs into the nucleus. ${ }^{21,22,27)}$

In this study, the concentration-dependent inhibition of FITC-protamine association by unlabeled protamine indicated that FITC-protamine is taken up via a specific pathway. In addition, when the time-course of FITC-protamine association was examined, the amount of FITC-protamine became maximum at up to $30 \mathrm{~min}$ after the start of incubation. The period necessary for the uptake amount to reach the maximum was shorter than that in the case of FITC-albumin (about $180 \mathrm{~min}$ ), a ligand which is taken up via receptor-mediated endocytosis. In the case of gentamicin uptake, which is inhibited by protamine, the uptake of $\left[{ }^{3} \mathrm{H}\right]$ gentamicin by $\mathrm{OK}$ cells increased with time up to $80 \mathrm{~min} .{ }^{9)}$ In addition, Jones et al. ${ }^{28)}$ reported that the maximal uptake of some CPPs such as antennapedia, TAT and polyarginine occurred between 1 and $3 \mathrm{~h}$. Thus, it is likely that the uptake of protamine is relatively more rapidly saturated than those of other ligands that are reported to be internalized via endocytosis.

We observed that FITC-protamine association is energyand temperature-dependent on flow cytometry and confocal microscopy. In addition, the vesicular distribution of FITCprotamine was observed in the cytoplasm of the $\mathrm{OK}$ cells that had been incubated with FITC-protamine for $30 \mathrm{~min}$ at $37^{\circ} \mathrm{C}$, but not at $4^{\circ} \mathrm{C}$. These findings indicated that FITC-protamine is internalized through endocytic pathway(s). Furthermore, FITC-protamine was detected in the nuclei in addition to its intracellular diffuse localization and its binding to the nuclear membranes of $\mathrm{OK}$ cells. Therefore, the distribution of FITC-protamine in the nucleus might occur following the diffusion of FITC-protamine from endocytic vesicles such as endosomes and lysosomes into the cytoplasm, though further studies are needed to clarify the precise pathway.

Interestingly, confocal microscopic analysis showed clear fluorescence in the cell membranes of the cells that had been incubated with FITC-protamine at $4^{\circ} \mathrm{C}$, whereas there was little fluorescence in the cell membranes in the case of incubation at $37^{\circ} \mathrm{C}$. In addition, as described above, the associated amount of FITC-protamine in OK cells was saturated at $30 \mathrm{~min}$ at $37^{\circ} \mathrm{C}$. Therefore, these observations might indicate down-regulation of the membrane surface receptor that is responsible for the internalization of FITC-protamine. The cell-surface receptors for epidermal growth factor (EGF) and hepatocyte growth factor (HGF) are reported to be downregulated by the administration of excess ligand, ${ }^{29,30)}$ which might support the speculation about the down-regulation in this study.

Endocytic pathways can be mainly divided into four types: macropinocytosis, clathrin-dependent endocytosis, caveolindependent endocytosis and clathrin, caveolin-independent endocytosis. ${ }^{31)}$ Based on the effects of pharmacological inhibi- 
tors of these endocytic pathways, both clathrin-dependent and caveolin-dependent pathways were suggested to be involved in the internalization of FITC-protamine in OK cells. On the other hand, a known macropinocytosis inhibitor, EIPA, significantly inhibited the association of FITC-protamine by OK cells, whereas cytochalasins B and D, other known macropinocytosis inhibitors, did not decrease FITC-protamine association. Since EIPA has been reported to block clathrinmediated endocytosis, ${ }^{32,33)}$ the inhibitory effect of EIPA on FITC-protamine association might be independent of macropinocytosis.

HSPGs are suggested to function as membrane surface receptors for CPPs such as the TAT peptide. ${ }^{26,27,34)}$ Therefore, we examined the effect of heparinase III, a heparin-degrading lyase, on the association of FITC-protamine by OK cells. Pretreatment with heparinase III significantly inhibited the association of FITC-protamine, but it was not completely abolished even with $100 \mathrm{mU}$ heparinase III (71.8\% of control). To obtain more information on the membrane surface binding receptor responsible for protamine uptake, ligand blotting with FITC-protamine was performed using crude membranes from OK cells and brush-border membranes from rat renal cortices. The ligand blot analysis revealed the presence of two major binding proteins with apparent molecular sizes of 410 and $100 \mathrm{kDa}$ in the membrane fractions from both OK cells and rat renal cortices. Gentamicin, which inhibits FITC-protamine uptake, is reported to bind to not only megalin but also cubilin. ${ }^{35)}$ The molecular sizes of megalin and cubilin are approximately 600 and $460 \mathrm{kDa}$, respectively. ${ }^{11,12)}$ Western blotting of the two membrane samples with cubilin antibodies gave corresponding to almost the same size as that of the larger molecular size detected on ligand blotting. However, as far as we know, whether or not protamine binds to cubilin has not been reported. Additional experiments are needed to identify the membrane surface receptor that plays an important role in protamine uptake in the kidneys.

In conclusion, we found that FITC-protamine is taken up via receptor-mediated endocytic pathways in OK cells. The membrane surface receptor that is involved in FITC-protamine uptake might partially overlap that for gentamicin uptake in OK cells. These findings might provide useful information for understanding the renal distribution of protamine exogenously injected.

Acknowledgments This work was supported in part by a Grant-in-Aid for Scientific Research from the Japan Society for the Promotion of Science (JSPS). We also wish to thank the Analysis Center of Life Science, Natural Science Center for Basic Research and Development, Hiroshima University, for the use of their facilities.

\section{REFERENCES}

1) Jaques LB. Protamine-antagonist to heparin. Can. Med. Assoc. J., 108, 1291-1297 (1973).

2) Owens DR. Insulin preparations with prolonged effect. Diabetes Technol. Ther., 13 (Suppl. 1), S5-S14 (2011).

3) Sorgi FL, Bhattacharya S, Huang L. Protamine sulfate enhances lipid-mediated gene transfer. Gene Ther., 4, 961-968 (1997).

4) Junghans M, Kreuter J, Zimmer A. Antisense delivery using protamine-oligonucleotide particles. Nucleic Acids Res., 28, E45 (2000).
5) Reynolds F, Weissleder R, Josephson L. Protamine as an efficient membrane-translocating peptide. Bioconjug. Chem., 16, 1240-1245 (2005).

6) DeLucia A 3rd, Wakefield TW, Kadell AM, Wrobleski SK, VanDort M, Stanley JC. Tissue distribution, circulating half-life, and excretion of intravenously administered protamine sulfate. ASAIO J., 39, M715-M718 (1993).

7) Butterworth J, Lin YA, Prielipp R, Bennett J, James R. The pharmacokinetics and cardiovascular effects of a single intravenous dose of protamine in normal volunteers. Anesth. Analg., 94, 514-522 (2002).

8) Butterworth J, Lin YA, Prielipp RC, Bennett J, Hammon JW, James RL. Rapid disappearance of protamine in adults undergoing cardiac operation with cardiopulmonary bypass. Ann. Thorac. Surg., 74, 1589-1595 (2002).

9) Nagai J, Komeda T, Yumoto R, Takano M. Effect of protamine on the accumulation of gentamicin in opossum kidney epithelial cells. J. Pharm. Pharmacol., 65, 441-446 (2013).

10) Zhai XY, Nielsen R, Birn H, Drumm K, Mildenberger S, Freudinger R, Moestrup SK, Verroust PJ, Christensen EI, Gekle M. Cubilin- and megalin-mediated uptake of albumin in cultured proximal tubule cells of opossum kidney. Kidney Int., 58, 1523-1533 (2000).

11) Christensen EI, Birn H. Megalin and cubilin: multifunctional endocytic receptors. Nat. Rev. Mol. Cell Biol., 3, 256-266 (2002).

12) Christensen EI, Verroust PJ, Nielsen R. Receptor-mediated endocytosis in renal proximal tubule. Pflugers Arch., 458, 1039-1048 (2009).

13) Park YJ, Liang JF, Ko KS, Kim SW, Yang VC. Low molecular weight protamine as an efficient and nontoxic gene carrier: in vitro study. J. Gene Med., 5, 700-711 (2003).

14) Lee TY, Park YS, Garcia GA, Sunahara RK, Woods JH, Yang VC. Cell permeable cocaine esterases constructed by chemical conjugation and genetic recombination. Mol. Pharm., 9, 1361-1373 (2012).

15) Handler JS. Studies of kidney cells in culture. Kidney Int., 30, 208-215 (1986)

16) Takano M, Hirozane K, Okamura M, Takayama A, Nagai J, Hori R. $p$-Aminohippurate transport in apical and basolateral membranes of the OK kidney epithelial cells. J. Pharmacol. Exp. Ther., 269, 970-975 (1994).

17) Schwegler JS, Heppelmann B, Mildenberger S, Silbernagl S. Receptor-mediated endocytosis of albumin in cultured opossum kidney cells: a model for proximal tubular protein reabsorption. Pflugers Arch., 418, 383-392 (1991).

18) Nagai J, Saito M, Adachi $Y$, Yumoto R, Takano M. Inhibition of gentamicin binding to rat renal brush-border membrane by megalin ligands and basic peptides. J. Control. Release, 112, 43-50 (2006).

19) Bradford MM. A rapid and sensitive method for the quantitation of microgram quantities of protein utilizing the principle of proteindye binding. Anal. Biochem., 72, 248-254 (1976).

20) Nagai J, Sato K, Yumoto R, Takano M. Megalin/cubilin-mediated uptake of FITC-labeled IgG by OK kidney epithelial cells. Drug Metab. Pharmacokinet., 26, 474-485 (2011).

21) Richard JP, Melikov K, Vives E, Ramos C, Verbeure B, Gait MJ, Chernomordik LV, Lebleu B. Cell-penetrating peptides. A reevaluation of the mechanism of cellular uptake. J. Biol. Chem., 278, 585-590 (2003).

22) Green I, Christison R, Voyce CJ, Bundell KR, Lindsay MA. Protein transduction domains: are they delivering? Trends Pharmacol. Sci., 24, 213-215 (2003).

23) Fretz M, Jin J, Conibere R, Penning NA, Al-Taei S, Storm G, Futaki S, Takeuchi T, Nakase I, Jones AT. Effects of $\mathrm{Na}^{+} / \mathrm{H}^{+}$exchanger inhibitors on subcellular localisation of endocytic organelles and intracellular dynamics of protein transduction domains HIV-TAT peptide and octaarginine. J. Control. Release, 116, 247-254 (2006).

24) Moestrup SK, Cui S, Vorum H, Bregengård C, Bjørn SE, Norris K, Gliemann J, Christensen EI. Evidence that epithelial glycoprotein 
330/megalin mediates uptake of polybasic drugs. J. Clin. Invest., 96, 1404-1413 (1995).

25) Vaara M, Fox J, Loidl G, Siikanen O, Apajalahti J, Hansen F, Frimodt-Møller N, Nagai J, Takano M, Vaara T. Novel polymyxin derivatives carrying only three positive charges are effective antibacterial agents. Antimicrob. Agents Chemother., 52, 3229-3236 (2008).

26) Tyagi M, Rusnati M, Presta M, Giacca M. Internalization of HIV-1 tat requires cell surface heparan sulfate proteoglycans. J. Biol. Chem., 276, 3254-3261 (2001).

27) Duchardt F, Fotin-Mleczek M, Schwarz H, Fischer R, Brock R. A comprehensive model for the cellular uptake of cationic cell-penetrating peptides. Traffic, 8, 848-866 (2007).

28) Jones SW, Christison R, Bundell K, Voyce CJ, Brockbank SM, Newham P, Lindsay MA. Characterisation of cell-penetrating peptide-mediated peptide delivery. Br. J. Pharmacol., 145, 1093-1102 (2005).

29) Yanai S, Sugiyama Y, Iga T, Fuwa T, Hanano M. Kinetic analysis of the downregulation of epidermal growth factor receptors in rats in vivo. Am. J. Physiol., 258, C593-C598 (1990).

30) Liu KX, Kato Y, Kino I, Nakamura T, Sugiyama Y. Ligand-induced downregulation of receptor-mediated clearance of hepatocyte growth factor in rats. Am. J. Physiol., 275, E835-E842 (1998).

31) Mayor S, Pagano RE. Pathways of clathrin-independent endocytosis. Nat. Rev. Mol. Cell Biol., 8, 603-612 (2007).

32) Ivanov AI, Nusrat A, Parkos CA. Endocytosis of epithelial apical junctional proteins by a clathrin-mediated pathway into a unique storage compartment. Mol. Biol. Cell, 15, 176-188 (2004).

33) Ivanov AI. Pharmacological inhibition of endocytic pathways: is it specific enough to be useful? Methods Mol. Biol., 440, 15-33 (2008).

34) Richard JP, Melikov K, Brooks H, Prevot P, Lebleu B, Chernomordik LV. Cellular uptake of unconjugated TAT peptide involves clathrin-dependent endocytosis and heparan sulfate receptors. $J$. Biol. Chem., 280, 15300-15306 (2005).

35) Tauris J, Christensen EI, Nykjaer A, Jacobsen C, Petersen CM, Ovesen T. Cubilin and megalin co-localize in the neonatal inner ear. Audiol. Neurootol., 14, 267-278 (2009). 